\title{
Apolipoprotein A-IV
}

National Cancer Institute

\section{Source}

National Cancer Institute. Apolipoprotein A-IV. NCI Thesaurus. Code C116605.

Apolipoprotein A-IV (396 aa, $45 \mathrm{kDa}$ ) is encoded by the human APOA4 gene. This protein is involved in both the transport and catabolism of chylomicrons and very low density lipoproteins. 